\title{
EFFECT OF FIELD DURATION ON YIELD AND YIELD ATTRIBUTES OF TOSSA JUTE VARIETIES AT DIFFERENT AGRO- ECOLOGICAL ZONES
}

\author{
J. Ferdous, M.S. Hossain, M.A. Alim and M.M. Islam ${ }^{1}$ \\ Agronomy Division and ${ }^{1}$ Planning, Training and Communication Division, \\ Bangladesh jute research Institute, Dhaka, Bangladesh \\ Corresponding E-mail: tanny.jannat92@gmail.com
}

(Received: 01 January 2020, Accepted: 18 February 2020)

Keywords: Jute, field duration, yield and location

\begin{abstract}
The experiment was conducted at Jute Agriculture Experimental Station (JAES), Manikganj; Jute Research Regional Station (JRRS), Rangpur and Jute Research Sub Station (JRSS), Jessore in 2017 to determine optimum field duration on yield and yield attributes of different tossa jute varieties. The experiment was laid-out in RCBD with three replications. Tossa jute varieties O-9897, BJRI Tossa Pat-5 and JRO-524 were used as planting materials. Crops were sown on last week of March to First week of April. The crops were harvested at different field durations (90 days, 100 days and 110 days after sowing) regarded as treatment. All crops were attained recommended cultural practices. Result showed that BJRI Tossa Pat-5 gave higher fibre production in 90 days at Manikganj and Rangpur (2.69 tha-1and 2.34tha-1 respectively)and 100 days field duration which was followed by JRO -524 (2.36 tha-1 and 2.24 tha-1 respectively)and O9897(2.21 tha-1 and 4.54 tha-1, respectively), however at 110 days JRO-524 (3.40 tha-1; 3.34 tha-1and 3.16 tha-1 respectively) gave the higher fibre yield compare other two varieties BJRI Tossa Pat-5 (3.20 tha-1; 3.14 tha-1and 3.12 tha-1 respectively) and O9897 (3.05 tha-1; 2.99 tha-1and 2.99 tha-1 respectively) at Manikganj, Rangpur and Jessore.
\end{abstract}

\section{Introduction}

Jute is a cash crop of Bangladesh. Jute (Corchorus spp.) is a common term used both for plant and the fibre obtained from the bark of the plants, Corchorus capsularis L. and C. olitorius L. There are over 30 species, which belongs to the genus Corchorus. It is grown in the summer season (Kharif-I) (Islam and Rahman, 2008). Jute being the most important cash crop plays a major role in agriculture and our national economy. It also holds an important position in the industrial sector of Bangladesh. Bangladesh produces world's best quality jute. The agricultural climate of Bangladesh is very much suitable for quality fibre production (Islam and Uddin, 2019). The productivity of jute had doubled from 1.50 t/ha during 1970-80 to about 2.04 t/ha during 2015-16. Development of high-yielding varieties were the one of the main specific technologies which made this possible. In 1970-80 decades about 15-16 lakh hectare of the total cultivable land was occupied by jute has now (2014-15) been reduced to about 7.00 to 8.00 lakh hectare which produced bout 16-17 lakh tons of fibre. However, national average yield is increased from 1.59 to 2.04 tons per hectare (BBS, 2015). It is happened due to use of high yielding jute varieties and production technologies, which together contributed toward higher yield. In Bangladesh, annually about 0.817 millions ha of land is cultivated for the production of about 0.162 million tons of fibre. To cultivate the said area, the farmers require about 5000 to 5500 tons of jute seed (Islam and Uddin, 2019). Many jute farmers use to produce jute crops by their own seeds to meet their requirements but such seeds are of poor in quality. One of the most important 
problems for jute production in Bangladesh is the unavailability of quality seed at proper time of sowing. Only about $10 \%$ to $15 \%$ quality jute seeds are supplied by different national agencies but the rest amount of quality seed is yet to be managed to supply (Islam and Rahman, 2008).

The government of Bangladesh has given more thrust to promote the jute seed industry by strengthening public sectors dealing with jute seed and also by sensitizing private sectors to reduce the dependence on imported jute seed. The activities of private sectors regarding jute seed are limited on seed import only (Islam and Ali, 2017).

But the present status of jute as a cash crop facing a problem for increasing preference to food crop due to population pressure. So, to sustain jute in cropping pattern, short duration is needed. Generally, jute takes 120 days field duration. Objectives of the present study is related to the field duration by keeping the optimum yield and quality of jute fibre. In this context two prominent tossa jute varieties O-9897 and O-795 were tested with JRO-524 for optimum field duration to assess the yield and quality of fiber.

\section{Materials and Methods}

The experiment was conducted at Jute Agriculture Experimental Station (JAES), Manikganj, Jute Research Regional Station, Rangpur and Jute Research Sub Station, Jessore during the year 2017. The experiments were laid out in RCBD with three replications. Unit plot size was $4.0 \mathrm{~m} \times 2.5 \mathrm{~m}$. Space between plot to plot and around the field was $1.0 \mathrm{~m}$ and between replications $1.5 \mathrm{~m}$. Two prominent tossa jute varieties O-9897 and BJRI Tossa Pat-5 (O-795) and JRO-524 were used as planting materials. Crops were sown on last week of March to First week of April. The crops were harvested at different field duration, (90 days, 100 days and 110 days after sowing) regarded as the treatment. Other cultural and intercultural practices were attended as per BJRI recommendation. Location wise average data of fibre yield and quality attributing characters were analyzed with the help of computer statistical package (MSTAT-C). The mean differences among the treatments were adjusted by Least Significant Difference (LSD) at 0.05 level (Gomez and Gomez, 1984).

\section{Results and Discussion}

Results revealed that yield and yield contributing characters like plant population, base diameter and plant height, fibre yield and stick yield were affected significantly at Manikganj. Fibre yield and stick yield were differed significantly due to variety irrespective of sowing date at Manikganj but at Rangpur and Jessore all the yield contributing data like plant population, base diameter and plant height, fibre yield and stick yield were not differed significantly (Table 1). BJRI Tossa Pat-5 gave numerically higher fibre yield (2.90 tha ${ }^{-1}$ and 2.75 tha $^{-1}$, respectively) which was followed by JRO -524 (2.70 tha ${ }^{-1}$ and 2.74 tha $^{-1}$, respectively) and varieties O-9897 (2.69 tha ${ }^{-1}$ and 2.53 tha $^{-1,}$ respectively) at Manikganj and Rangpur. JRO-524 gave numerically higher fibre yield $\left(3.22\right.$ tha $\left.^{-1}\right)$ which was followed by tossa jute varieties BJRI Tossa Pat-5 (2.67 tha $\left.{ }^{-1}\right)$ and O-9897 $\left(2.54\right.$ tha $\left.^{-1}\right)$ at Jessore.

It was observed that fibre yield and stick yield were differed significantly due to variety irrespective of sowing date at Manikganj but at Rangpur and Jessore all the yield contributing data were not differed significantly (Table 2). Crop harvested on 110 days gave the highest fibre and stick yields $\left(3.22\right.$ tha $^{-1}$ and 6.56 tha $^{-1}$, respectively). Plant height $(3.05 \mathrm{~m})$ and base diameter $(17.05 \mathrm{~mm})$ were also found the highest at the same date. The crop harvested on 90 days recorded the lowest fibre and stick yields (2.42 tha ${ }^{-1}$ and 4.92 tha $^{-1}$, respectively) at Manikganj. At Rangpur, yields and all the yield contributing parameters like plant population, base diameter and plant height, fibre yield and stick yield were not differed significantly due to longer field duration irrespective of variety (Table 2). Crop harvested on 110 days gave the highest fibre and stick yields $\left(3.16\right.$ tha $^{-1}$ and 6.17 tha $^{-1}$, respectively). 
Table 1. Effect of variety irrespective of field duration on fibre yield and yield components of tossa jute at different locations

\begin{tabular}{|c|c|c|c|c|c|c|}
\hline Location & Treatment & $\begin{array}{c}\text { Plant } \\
\text { population } \\
\left(\mathrm{m}^{-2}\right)\end{array}$ & $\begin{array}{l}\text { Plant } \\
\text { height } \\
(\mathrm{m})\end{array}$ & $\begin{array}{c}\text { Base } \\
\text { diameter } \\
(\mathrm{mm})\end{array}$ & $\begin{array}{l}\text { Fibre } \\
\text { yield } \\
\left(\text { tha }^{-1}\right)\end{array}$ & $\begin{array}{l}\text { Stick yield } \\
\quad\left(\text { tha }^{-1}\right)\end{array}$ \\
\hline \multirow{5}{*}{ Manikganj } & O-9897 & 32.98 & 2.60 & 14.44 & 2.59 & 5.55 \\
\hline & BJRI Tossa Pat-5 & 33.95 & 2.83 & 15.38 & 2.90 & 5.99 \\
\hline & JRO-524 & 33.82 & 2.70 & 14.99 & 2.70 & 5.62 \\
\hline & $\operatorname{LSD}_{(0.05)}$ & 0.367 & 0.055 & 0.084 & 0.062 & 0.077 \\
\hline & $\% \mathrm{CV}$ & 1.09 & 2.06 & 0.55 & 2.23 & 0.67 \\
\hline \multirow{5}{*}{ Rangpur } & O-9897 & 34.93 & 2.84 & 14.20 & 2.53 & 5.26 \\
\hline & BJRI Tossa Pat-5 & 34.62 & 2.89 & 15.22 & 2.75 & 5.76 \\
\hline & JRO-524 & 34.39 & 2.88 & 14.91 & 2.74 & 5.51 \\
\hline & $\operatorname{LSD}_{(0.05)}$ & NS & NS & NS & NS & NS \\
\hline & $\% \mathrm{CV}$ & 1.02 & 0.85 & 0.35 & 2.23 & 0.71 \\
\hline \multirow{5}{*}{ Jessore } & O-9897 & 33.84 & 2.72 & 14.12 & 2.54 & 5.31 \\
\hline & BJRI Tossa Pat-5 & 33.31 & 2.76 & 14.89 & 2.67 & 5.53 \\
\hline & JRO-524 & 32.89 & 2.88 & 15.40 & 2.74 & 5.83 \\
\hline & $\operatorname{LSD}(0.05)$ & NS & NS & NS & NS & NS \\
\hline & $\% \mathrm{CV}$ & 0.54 & 0.94 & 2.55 & 1.47 & 0.73 \\
\hline
\end{tabular}

Legend: NS $=$ Not-significant

Table 2. Effect of field duration irrespective of variety on fibre yield and yield components of tossa jute at different locations

\begin{tabular}{|c|c|c|c|c|c|c|}
\hline Location & Treatment & $\begin{array}{c}\text { Plant } \\
\text { population } \\
\left(\mathrm{m}^{-2}\right)\end{array}$ & $\begin{array}{l}\text { Plant height } \\
\text { (m) }\end{array}$ & $\begin{array}{c}\text { Base } \\
\text { diameter } \\
(\mathrm{mm})\end{array}$ & $\begin{array}{l}\text { Fibre yield } \\
\left(\text { tha }^{-1}\right)\end{array}$ & $\begin{array}{l}\text { Stick yield } \\
\left(\text { tha }^{-1}\right)\end{array}$ \\
\hline \multirow{5}{*}{ Manikganj } & 90 days & 34.47 & 2.47 & 13.22 & 2.42 & 4.92 \\
\hline & 100 days & 33.71 & 2.60 & 14.55 & 2.56 & 5.68 \\
\hline & 110 days & 32.56 & 3.05 & 17.05 & 3.22 & 6.56 \\
\hline & $\operatorname{LSD}_{(0.05)}$ & 0.367 & 0.055 & 0.084 & 0.062 & 0.077 \\
\hline & $\% \mathrm{CV}$ & 1.09 & 2.06 & 0.55 & 2.23 & 0.67 \\
\hline \multirow{5}{*}{ Rangpur } & 90 days & 35.72 & 2.61 & 13.06 & 2.24 & 4.75 \\
\hline & 100 days & 34.68 & 2.86 & 14.39 & 2.61 & 5.60 \\
\hline & 110 days & 33.54 & 3.13 & 16.89 & 3.16 & 6.17 \\
\hline & $\operatorname{LSD}_{(0.05)}$ & NS & NS & NS & NS & NS \\
\hline & $\% \mathrm{CV}$ & 1.02 & 0.85 & 0.35 & 2.23 & 0.71 \\
\hline \multirow{5}{*}{ Jessore } & 90 days & 34.42 & 2.53 & 13.13 & 2.24 & 4.81 \\
\hline & 100 days & 33.40 & 2.78 & 14.44 & 2.62 & 5.66 \\
\hline & 110 days & 32.22 & 3.05 & 16.83 & 3.09 & 6.20 \\
\hline & $\operatorname{LSD}(0.05)$ & NS & NS & NS & NS & NS \\
\hline & $\% \mathrm{CV}$ & 0.54 & 0.94 & 2.55 & 1.47 & 0.73 \\
\hline
\end{tabular}

Legend: NS = Not-significant 
Plant height $(3.13 \mathrm{~m})$ and base diameter $(16.89 \mathrm{~mm})$ were also highest at the same date. The crops that harvested on 90 days recorded the lowest fibre and stick yield production $\left(2.24\right.$ tha $^{-1}$ and $4.75 \mathrm{tha}^{-1}$, respectively). At the same time similar result found at Jessore (Table 2). Crop harvested on 110 days gave the highest fibre and stick yields (3.09 tha ${ }^{-1}$ and 6.20 tha $^{-1}$, respectively). Plant height $(3.05 \mathrm{~m})$ and base diameter $(16.83 \mathrm{~mm})$ were also found the highest at the same date. The crop harvested on 90 days recorded the lowest fibre and stick yields (2.42 tha ${ }^{-1}$ and 4.81 tha $^{-1}$, respectively) at Jessore. Weng et al. (1990) reported similar findings in Kenaf and jute.

In case of interaction effect of variety and field duration was observed that at Manikganj plant population, base diameter and plant height, fibre yield and stick yield were not differed significantly due to interaction effect of variety and field duration. Highest fibre yield and stick yield was recorded at BJRI Tossa Pat-5 (2.69 tha ${ }^{-1}$ and 5.36 tha $^{-1}$, respectively) which was followed by JRO -524 (2.36 tha ${ }^{1}$ and 4.85 tha $^{-1}$, respectively) and varieties $0-9897$ (2.21 tha ${ }^{-1}$ and 4.54 tha $^{-1,}$ respectively) at 90 days (Figure 1). At 100 days, BJRI Tossa Pat-5 also gave higher fibre yield $\left(2.82\right.$ tha $\left.^{-1}\right)$ which was followed by varieties O-9897 $\left(2.51\right.$ tha $\left.^{-1}\right)$ and JRO $-524\left(2.35\right.$ tha $\left.^{-1}\right)$ but at 110 days JRO -524 gave the higher fibre yield $\left(3.40\right.$ tha $\left.^{-1}\right)$ which was followed by varieties BJRI Tossa Pat-5 (3.20 tha $\left.{ }^{-1}\right)$ and O-9897 (3.05 tha $\left.^{-1}\right)$. The results were in agreement with Islam et al. (1995) and Hsu and Chi (1976).

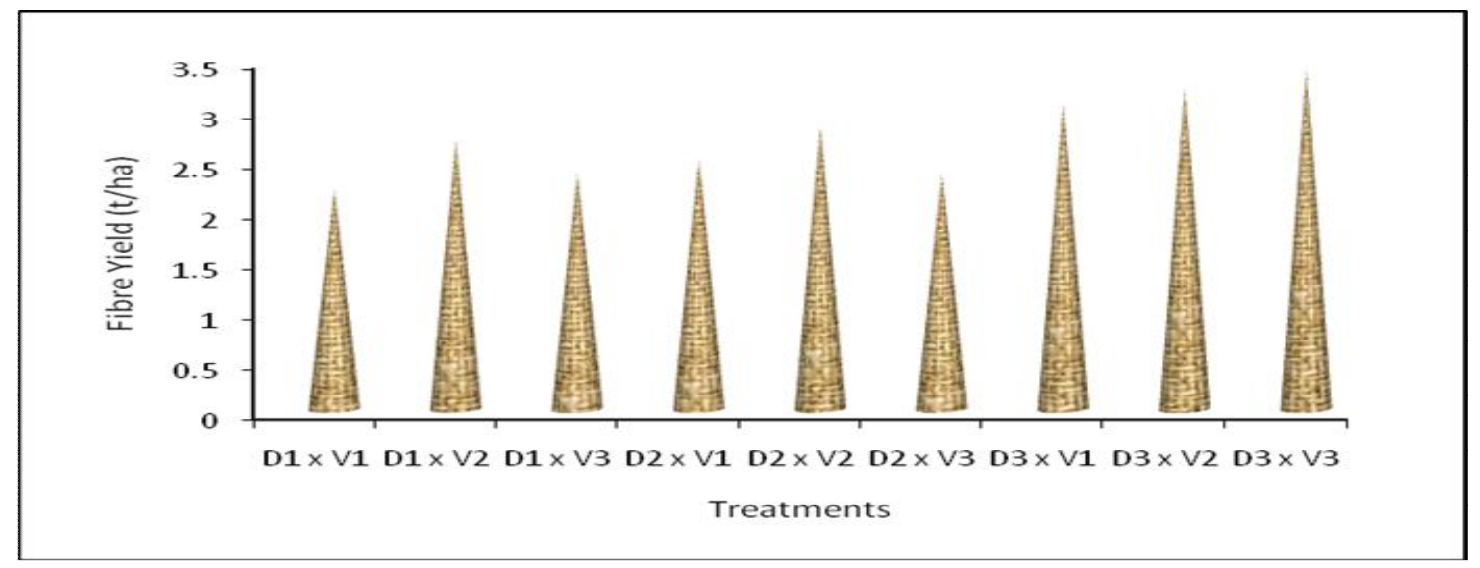

Legend: $\mathrm{V}_{1}=\mathrm{O}-9897, \mathrm{~V}_{2}=\mathrm{O}-795, \mathrm{~V}_{3}=$ JRO-524; $\mathrm{D}_{1}=90$ days, $\mathrm{D}_{2}=100$ days, $\mathrm{D}_{3}=110$ days.

Fig. 1. Interaction effect of variety and field duration on fibre yield and yield components of tossa jute at Manikganj.

In case of Rangpur, it was observed that plant population, base diameter and plant height, fibre yield and stick yield fibre yields and stick yield were differed significantly due to interaction effect of variety and field duration. The highest fibre yield and stick yield was obtained from BJRI Tossa Pat-5 (2.34 tha $^{-1}$ and 5.11 tha $^{-1}$, respectively) which was followed by JRO -524 (2.24 tha ${ }^{-1}$ and 4.73 tha $^{-1}$, respectively) and varieties O-9897 (2.15 tha ${ }^{-1}$ and 4.42 tha $^{-1}$, respectively) at 90 days (Figure 2). BJRI Tossa Pat-5 also gave higher fibre yield $\left(2.76\right.$ tha $\left.^{-1}\right)$ which was followed by JRO $-524\left(2.63\right.$ tha $\left.^{-1}\right)$ and varieties $0-9897\left(2.45\right.$ tha $\left.^{-1}\right)$ at 100 days but JRO -524 gave the higher fibre yield $\left(3.34\right.$ tha $\left.^{-1}\right)$ which was followed by varieties BJRI Tossa Pat-5 $\left(3.14\right.$ tha $\left.^{-1}\right)$ and O-9897 $\left(2.99\right.$ tha $\left.^{-1}\right)$ at 110 days. 


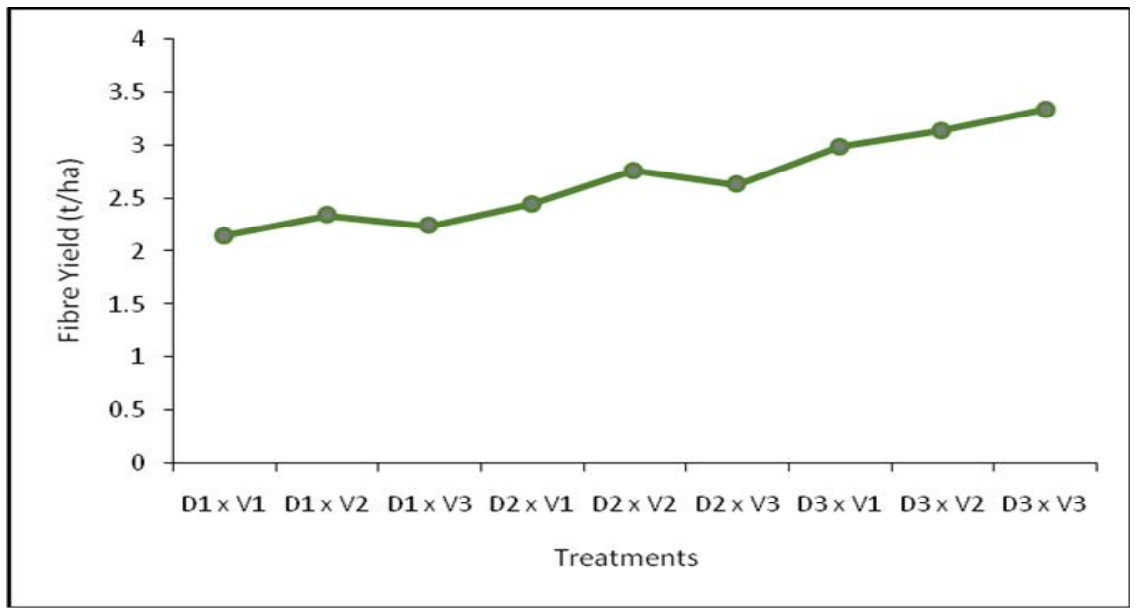

Legend: $\mathrm{V}_{1}=\mathrm{O}-9897, \mathrm{~V}_{2}=\mathrm{O}-795, \mathrm{~V}_{3}=$ JRO-524; $\mathrm{D}_{1}=90$ days, $\mathrm{D}_{2}=100$ days, $\mathrm{D}_{3}=110$ days.

Fig. 2. Interaction effect of variety and field duration on fibre yield and yield components of tossa jute at Rangpur.

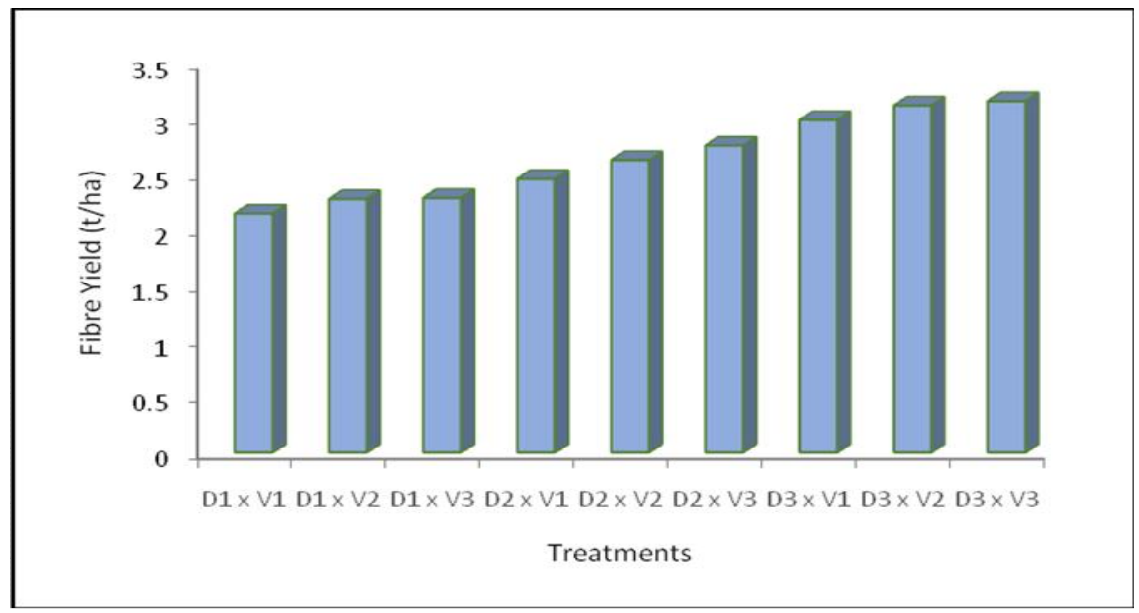

Legend: $\mathrm{V}_{1}=$ O-9897, $\mathrm{V}_{2}=$ BJRI Tossa Pat-5, $\mathrm{V}_{3}=$ JRO-524; $\mathrm{D}_{1}=90$ days, $\mathrm{D}_{2}=100$ days, $\mathrm{D}_{3}=110$ days.

Fig. 3. Interaction effect of variety and field duration on fibre yield and yield components of tossa jute at Jessore.

At Jessore, plant population, base diameter and plant height, fibre yield and stick yield fibre yields and stick yield were differed significantly due to interaction effect of variety and field duration. Result showed that the highest fibre yield and stick yield was obtained from JRO -524 (2.29 tha ${ }^{-1}$ and 5.17 tha $^{-}$ ${ }^{1}$, respectively) which were followed by tossa variety BJRI Tossa Pat-5 (2.28 tha ${ }^{-1}$ and 4.79 tha $^{-1}$, respectively) and varieties O-9897 (2.15 tha ${ }^{-1}$ and 4.48 tha $^{-1}$, respectively) at 90 days (Figure 3). At 100 days, JRO -524 also gave higher fibre yield $\left(2.76\right.$ tha $\left.^{-1}\right)$ which was followed by tossa variety BJRI Tossa Pat-5 $\left(2.63\right.$ tha $\left.^{-1}\right)$ and varieties O-9897 $\left(2.46\right.$ tha $\left.^{-1}\right)$ and at 110 days JRO-524 gave the higher fibre yield $\left(3.16\right.$ tha $^{-1}$ ) which was followed by varieties BJRI Tossa Pat-5 (3.12 tha $\left.{ }^{-1}\right)$ and O-9897 (2.99 tha $\left.^{-1}\right)$. Similar results were found by Islam et al. (1995) and Hsu and Chi (1976). 


\section{Conclusion}

BJRI Tossa Pat-5 gave higher fibre production in 90 days at Manikganj and Rangpur $\left(2.69\right.$ tha $^{-1}$ and 2.34 tha $^{-1}$ respectively)and 100 days field duration which was followed by JRO -524 (2.36 tha ${ }^{-1}$ and 2.24 tha ${ }^{-1}$ respectively)and $0-9897\left(2.21\right.$ tha $^{-1}$ and 4.54 tha $^{-1,}$ respectively), however at 110 days JRO-524 (3.40 tha $^{-1}$; 3.34 tha $^{-1}$ and 3.16 tha $^{-1}$ respectively) gave the higher fibre yield compare other two varieties BJRI Tossa Pat-5 (3.20 tha ${ }^{-1} ; 3.14$ tha $^{-1}$ and 3.12 tha $^{-1}$ respectively) and O-9897 (3.05 tha-1; 2.99 tha 1 and 2.99 tha $^{-1}$ respectively) at Manikganj, Rangpur and Jessore.

\section{References}

BBS. 2015. Yearbook of Agricultural Statistics of Bangladesh. Ministry of Planning, Government of the People's Republic of Bangladesh, Dhaka, Bangladesh.

Gomez, K.A. and A.A. Gomez. 1984. Statistical Procedures for Agricultural Research. Second Edn. John Wiley and Sons Inc., New York. pp.304-307.

Hsu, S.T. and C.Y. Chi. 1976. Studies on the effect different harvesting periods on yield and quality of jute fibre. Field Crop Abs. 29(3): 190.

Islam, M.M. and M.S. Ali. 2017. Economic importance of jute in Bangladesh: production, research achievements and diversification. Intl. J. Econ. Theory Appl. 4(6): 45-57.

Islam, M.M. and M.S. Ali. 2017. Agronomic research advances in jute crops of Bangladesh. AASCIT J. Biol. 3(6): 34-46.

Islam, M.M., K.R. Haque, A.A. Miah, N. Nuruzzaman and M.A. Rahman. 1995. Response of stage of harvest to yield, yield components and quality of jute fibre. Bangladesh J. Jute Fib. Res. 20(1): 915.

Islam, M.M. and M. Rahman. 2008. Hand book on Agricultural Technologies of Jute, Kenaf and Mesta crops. Bangladesh Jute Research Institute, Manikmia Avenue, Dhaka-1207, Bangladesh. p.92.

Islam, M.M. and N. Uddin. 2019. Research and development advances of jute seed in Bangladesh: A review, Haya Saudi J. Life Sci. 4(2): 52-68.

Rahman, M.M., M.L. Rahman, A.K. Azad, M. Rahman and M.M. Hussain. 2003. Impact of component technologies in jute production. Bangladesh J. Jute Fib. Res. 24(1-8): 21-26.

Weng, C.H., N.X. Lai and B.F. Shao. 1990. Effect of harvesting dates on fibre yield and quality of Kenaf and jute. Field Crop Abst. 43(11): 1076. 